\title{
KESADARAN WAJIB PAJAK RESTORAN DALAM KEPATUHAN PELAPORAN PAJAK MENGGUNAKAN APLIKASI E-SPTPD (ELEKTRONIK-SURAT PEMBERITAHUAN PAJAK DAERAH) DI KOTA DEPOK
}

\author{
Adinda Dwi Syahnaz \\ Universitas Pembangunan Nasional Veteran Jakarta \\ Corresponding Author: e-mail: adinda.dwi@upnvj.ac.id
}

\begin{abstract}
The purpose of this study is to determine the awareness of restaurant taxpayers in tax reporting compliance using the E-SPTPD application in Depok City. The method used in this research is a qualitative method with an interpretive paradigm and an ethnometodological approach. The sample of this study is restaurant owners who are registered and not yet registered as restaurant taxpayers in Depok City. The results of this study indicate that the lack of awareness of restaurant owners in restaurant tax reporting. This is due to the lack of knowledge of restaurant owners on taxation and the remote location makes it difficult for tax officers in the field to know the existence of the restaurant. The socialization carried out by the Depok City Regional Finance Agency has also not resulted in restaurant owners' awareness of their tax obligations because there are still many restaurant owners who are not present at the socialization.
\end{abstract}

Keywords: Restaurant Tax, Local Tax, E-SPTPD, Taxpayer Awareness and Compliance

\begin{abstract}
ABSTRAK
Tujuan dari penelitian ini untuk mengetahui kesadaran wajib pajak restoran dalam kepatuhan pelaporan pajak menggunakan aplikasi E-SPTPD di Kota Depok. Metode yang digunakan dalam penelitian ini adalah metode kualitatif dengan paradigma intepretif dan pendekatan etnometodologi. Sampel dari penelitian ini adalah pemilik restoran yang sudah terdaftar dan belum terdaftar sebagai wajib pajak restoran di Kota Depok. Hasil penelitian ini menunjukan bahwa kurangnya kesadaran pemilik restoran dalam pelaporan pajak restoran. Hal ini disebabkan kurangnya pengetahuan pemilik restoran terhadap perpajakan dan lokasi yang terpencil membuat petugas pajak yang ada dilapangan sulit mengetahui keberadaan restoran tersebut. Sosialisasi yang dilakukan oleh Badan Keuangan Daerah Kota Depok juga tidak membuahkan hasil kesadaran para pemilik restoran terhadap kewajiban perpajakannya karena masih banyak pemilik restoran yang tidak hadir dalam sosialisasi tersebut.
\end{abstract}

Kata Kunci : Pajak Restoran, Pajak Daerah, E-SPTPD, Kesadaran dan Kepatuhan Wajib Pajak 


\section{PENDAHULUAN}

Mengembangnya zaman era globalisasi saat ini dapat dilihat dari berbagai perubahan dalam beberapa aspek kehidupan manusia saat ini. Perkembangan dibidang teknologi setap tahun juga mendapat perkembangan pesat, khususnya bagian dibidang elektronika yang membawa kemudahan untuk melakukan tugas arsip, kemajuan teknologi berpengaruh pada kearsipan pada adanya perubahan baru dengan proses pengarsipan yaitu adanya arsip elektronik. Tujuan utama dengan adanya arsip elektronik supaya mempermudah dan mempunyai tingkat resiko yang sangat rendah.

Suatu instansi memerlukan adanya sistem informasi yang berfungsi sebagai alat untuk membantu suatu tujuan melalui penyediaan informasi. Perolehan alat bantu yaitu perolehan tujuan lewat penyediaan informasi. Keberhasilan sistem informasi bertujuan dengan bagaimana sistem dapat memproses data lalu menghasilkan informasi yang benar, akan tetapi ditentukan juga kesesuaiannya dengan lingkungan pekerjaan, walaupun sistem informasi sudah menggunakan teknologi canggih sistem belum bisa dibilang berhasil apabila pemakasi sistem informasi tidak dapat menerima dan bahkan segan untuk menggunakannya (Sayekti \& Putarta, 2016).

Unsur penting penerapan suatu sistem informasi yaitu penerimaan dengan sitem informasi tersebut. Untuk suatu instansi sistem informasi sangatlah berguna sebagai alat untuk membantu pencapaian tujuan instansi dengan penyediaan informasi. Keberhasilan sistem informasi tidak dengan ditentukan oleh bagaimana sistem dapat memproses masukan dengan menghasilkan informasi dengan baik, akan tetapi juga bagaimana dengan pengguna mau menerima dan menggunakan sehingga dapat mencapai tujuan instansi ataupun organisasi.

Walikota Depok meresmikan sistem pelaporan pajak daerah secara online melalui e-SPTPD berdasarkan peraturan Walikota Depok nomor 43 tahun 2015, pelaporan pajak daerah secara online ini merupakan satu inovasi menuju komitmen pemerintah Kota Depok untuk terus meningkatkan pelayanan, trasparansi dan akuntabilitas. Aplikasi elektronik-Surat Pemberitahuan Pajak Daerah yang dimasukan lewat aplikasi website yang sudah dipersiapkan oleh Badan Keuangan Daerah (BKD) Kota Depok. Dengan adanya sistem ini, BKD mempermudah untuk para wajib pajak menyampaikan SPTPD dengan tidak datang ke kantor Badan Keuangan Daerah Kota Depok, sehingga memudahkan petugas menghitung jumlah pendapatan pajak yang didapatkan setiap bulannya melalui sistem yang sudah disediakan oleh BKD Kota Depok.

Ketentuan kewajiban perpajak yaitu, dimana wp (wajib pajak) diharuskan melakukan kewajiban pajaknya dengan cara melaporkan, membayarkan, dan mempertanggung jawabkan perhitungan perpajakannya sesuai dengan peraturan yang telah ditetapkan. Oleh karenanya didalam hal tersebut wp diharuskan melakukan sendiri pengisian e-SPTPD dan melaporkan e-SPTPD tersebut. Dengan adanya perkembangan teknologi informasi untuk mendukung penerapan tugas pokok BKD supaya meningkatkan penerimaan pajak daerah, dari beberapa upaya yang telah 
dikerjakan BKD dapat menigkatkan system teknologi informasi dalam melakukan pelayanan perpajakan kepada wajib pajak.

\section{METODE PENELITIAN}

Strategi yang digunakan oleh peneliti didalam penelitian ini adalah kualitatif. Peneliti ingin menganalisis serta menjelaskan tingkat kesadaran wajib pajak restoran dalam kepatuhan pelaporan pajak menggunakan aplikasi E-SPTPD, menggambarkan dari salah satu bagian pajak daerah yang ada pada Kota Depok. (Suradiansyah et al., 2019) menjelaskan maka penelitian kualitatif, penelitian yang bertujuan guna memahami fenomena tentang yang berhubungan dengan apa yang dialami oleh subjek penelitian, misalnya perilaku dari objek yang diamati, pengertian atau persepsi, motivasi atau tekad, tindakan, dan beberapa hal lainnya.

Penelitian kualitatif ini juga mencoba guna meminta orang lain untuk mengungkapkan beragam pikiran mereka mengenai salah satu dari topik, tidak memberikan mereka banyak arahan pedoman bagaimana yang harus mereka katakan.

Paradigma interpretif, dikerjakan untuk membangun pemahaman untuk membantu agar mengerti dan menginterpretasi apa yang sudah ada didalam peristiwa, seperti manusia meletakkan makna pada masalah yang terjadi. Pendekatan Etnometodologi sangat sesuai dengan penelitian yang akan peneliti ambil, karena yang terjadi dalam penelitian ini yaitu mengenai kesadaran wajib pajak dalam kepatuhan pelaporan pajak menggunakan aplikasi E-SPTPD oleh pengusaha restoran. Sehingga dalam penelitian ini mengarah pada Etnometodologi.

Etnometodologi usaha memahami bagaimana cara orang menerangkan, menguraikan, dan melihat bagaimana keteraturan dunia mereka.kata lain dari penelitian ini bekerja dengan cara kualitatif agar peka terhadap kebutuhan menurut masyarakat atau menangguhkan asumsi tentang pandangannya daripada mempertimbangkannya.

Pendekatan ini sama dengan halnya proses dari penelitian yang melibatkan pemilik restoran dan kebijakan peraturan daerah kepada ketetapan pajak restoran yang dilakukan BKD Kota Depok agar merapikan pemilik restoran supaya mendaftarkan diri sebagai wajib pajak restoran. Keterlibatan beberapa informan dalam penelitian maka dapat terlihat bahwa ada suatu perbedaan cara pandang pemilik restoran yang tidak mendaftrkan diri sebagai wajib pajak, dan tidak membayarkan pajak restorannya tidak sesuai dengan peraturan daerah Kota Depok. 


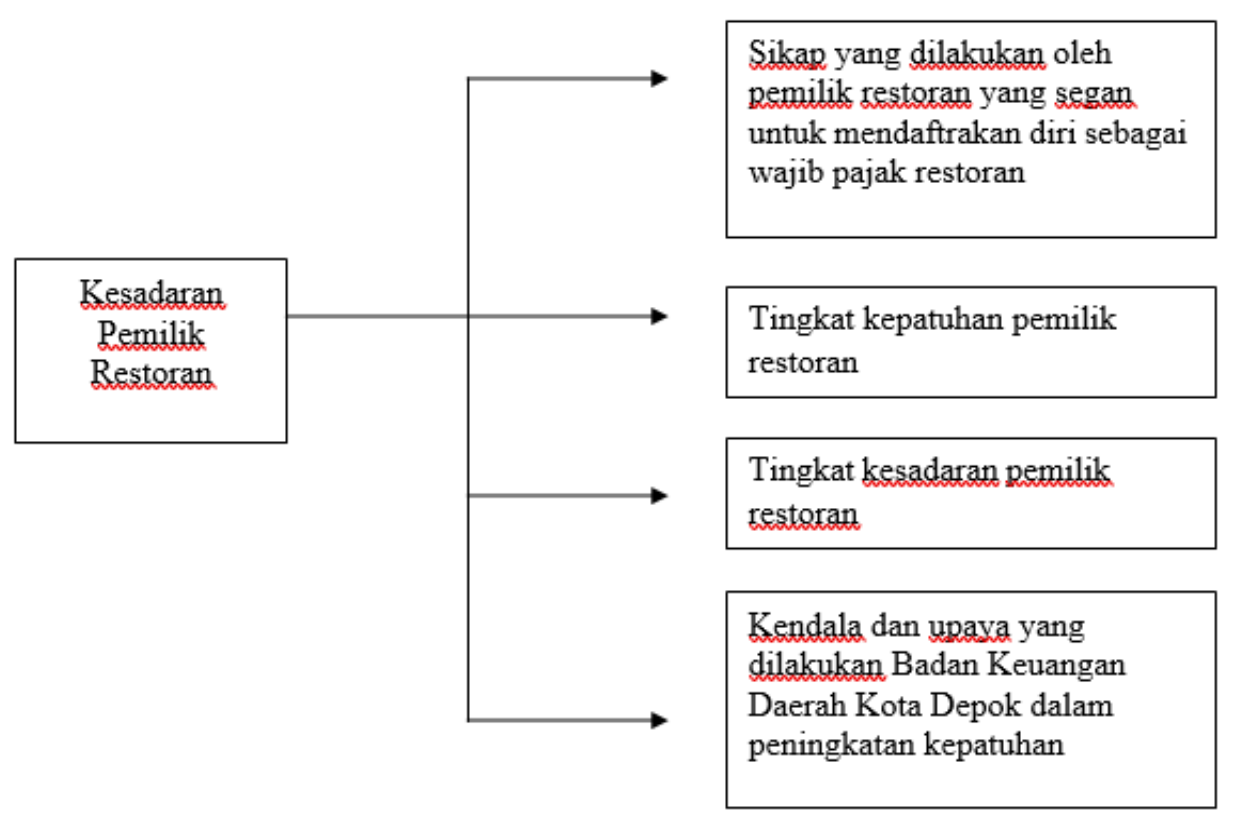

Gambar 1. Hasil Temuan Peneliti

Sesudah mendapatkan penemuan, akan dilakukan pengolahan data menggunakan triangulasi, dimana data tersebut diperoleh seorang informan yang akan di uji ulang dengan menanyakan hal yang sama dengan informan yang lain tetapi dengan metode yang berbeda. Hasil dari temuan yang diperoleh mendapatkan uraian lebih rinci da mendalam.

\section{PEMBAHASAN}

A. Pengertian Pajak

Pajak adalah iuran yang wajib bagi masyarakat untuk negara ataupun pemerintah berdasarkan Undang-Undang, bersifat dipaksakan dan terutang bagi yang wajib membayarkannya tanpa mendapat balasan secara langsung, serta dapat membiayai pengeluaran kas negara dalam menjalankan pemerintahan dan pembangunan (Suradiansyah et al., 2019).

Wajib pajak perlu melaksanakan peraturan dengan baik,benar,dan sukarela. Maka dapat diartikan kesadaran wajib pajak merupakan suatu kondisi wajib pajak mengetahui, menghargai, dan mentaati peraturan perpajakan yang berlaku dan memiliki kesungguhan maupun keinginam untuk memenuhi kewajiban perpajakannya. Pembayaran kewajiban perpajakan oleh pembayar pajak dalam rangka memberikan kontribusinya untuk pembangunan negara dan diharapkan dalam pemenuhannya dilakukan dengan sukarela. Kepatuhan menjadi aspek seberapa pentingnya untuk mengingat sistem perpajakan di Indonesia yang menganut system self assessment, dalam proses mutlak memberikan kepercayaan bagi wajib pajak untuk menghitung, membayar, dan melaporkan kewajibannya.

Masyarakat sangat mempengaruhi pertumbuhan ekonomi daerah, kesejahteraan daerah dan dapat berpengaruh pada pertumbuhan pendapatan asli daerah. Pertumbuhan pendapatan asli daerah tidak terlepas dari campur tangan pemerintah dalam bersosialisasi dengan 
masyarakat, poin dari swasta dapat mewujudkan bermacam-macam bidang usaha yang pada saatnya berperan besar dalam pemasukan kas daerah

Restoran adalah suatu usaha yang menyediakan, menyajikan, menghidangkan, dan menjual makanan ataupun minuman bagi masyarakat umum ditempat usahanya berdiri disebagian ataupun keseluruh bangunan permanen dilengkapi dengan peralatan serta perlengkapan proses pembuatan dan penyimpanan yang telah mempunyai surat keputusan sebagai tempat restoran dari instansi yang bersangkutan

Dasar dari pengenaan Pajak, jumlah yang harus dibayarkan konsumen kepada restoran. Dari hasil jumlah tersebut dikalikan 10\% merupakan tarif dari pajak restoran (Anugrahi et al., 2018), termasuk di dalamnya rumah makan yang bersangkutan, warung makan yang bersangkutan, kafe, bar, pedagang kaki lima, kolam pancing atau usaha lain sejenis, yang disertai fasilitas penyantapannya ditempat maupun disantap di tempat lain, yang disertai dengan fasilitas take way.

Objek pajak restoran yaitu jasa pelayanan yang diberikan oleh restoran meliputi pelayanan, penjualan makanan ataupun minuman yang dikonsumsi oleh konsumen baik dikonsumsi ditempat pelayanan maupun ditempat lain atau di take way. Pada UU no 28 thn 2009 menyebutkan bahwa yang bukan termasuk objek pajak restoran yaitu pelayanan yang diberikan oleh restoran dengan nilai penjualannya tidak melebihi batas yang ditetapkan dengan peraturan daerah (Sucandra \& Supadmi, 2016).

Penyampaian SPTPD (Surat Pemberitahuan Pajak Daerah) dilakukan paling lambat dalam 20 hari setelah berakhirnya masa perpajakan. Apabila batas waktu penyampaian SPTPD terjadi pada hari libur (weekend) maka batas waktu untuk penyampaian SPTPD terjadi pada hari kerja setelahnya. Peyampaian SPTPD dilampiri dengan beberapa dokumen yang telah ditetapkan oleh kepala daerah.

Perpanjangan penyampaian SPTPD (Surat Pemberitahuan Pajak Daerah) dapat diajukan secara tertulis dengan alasan yang jelas dan disahkan oleh kepala daerah atau pejabat yang ditunjuk selambat-lambatnya sebelum berakhirnya masa waktu penyampaian SPTPD dengan melampirkan beberapa dokumen perhitungan sementara pajak yang terutang yang harus dibayarkan.

Pembetulan surat pemberitahuan perlu disampaikan paling lama 2 tahun sebelum kadaluwarsa penetapan surat. Dalam hal ini wajib pajak harus membetulkan sendiri surat pemberitahuan pajak daerah yang mengakibatkan bebeberapa hutang pajak menjadi lebih besar, oleh karenanya dikenai sanksi administrasi berupa bunga $2 \%$ per bulan karena jumlah pajak yang kurang bayar, dihitung sejak jatuh tempo pembayaran sampai dengan tanggal pembayaran yang dihitung dalam satu bulan penuh.

Setiap orang yang melakukannya secara sengaja tidak menyampaikan SPTPD (Surat Pemberitahuan Pajak Daerah) tersebut ataupun menyampaikan SPTPD tetapi isinya tidak benar dan tidak lengkap itu dapat merugikan negara, sehingga dapat memunculkan kerugian pada pendapatan negara, dapat dipidana dengan cara pidana penjara paling 
singkat 6 bulan dan paling lama 6 tahun serta denda paling sedikit 2x dari jumlah pajak terutang, yang tidak kurang dapat dibayar dan paling banyak 4x jumlah dari pajak terutang yang tidak kurang dibayar.

SKPDKB (Surat Ketetapan Pajak Daerah Kurang Bayar), Surat ini yang dapat menentukan berapa besarnya jumlah pokok pajak, kredit pajak, kurangnya pokok pembayaran pajak, besarnya sanksi administrasi dan jumlah yang masih harus dibayar

SKPDKBT (Surat Ketetapan Pajak Daerah Kurang Bayar Tambahan), Surat ini yang menentukan berapa jumlah tambahan atas pajak yang sudah ditetapkan. Munculnya ketetapan tersebut biasanya karena mempunyai data baru yang tidak terungkap pada pemeriksaan sebelumnya pada tahun pajak yang bersangkutan yang menjadi penambahan jumlah pajak terutang.

SKPDN (Surat Ketetapan Pajak Daerah Nihil), Surat ini yang menentukan berapa jumlah pajak terutang dan sama besarnya dengan kredit pajak atau pajak tidak terutang dan tidak mempunyai kredit pajak. SKPDN dapat diterbitkan ketika jumlah pajak terutang sama besar dengan kredit pajak. Yang dimaksudkan dengan ini yaitu memberikan kepastian hukum pajak terutang yang dibayar dan dilaporkan wajib pajak sudah sesuai dengan peraturan daerah tentang pajak daerah yang dimaksud.

STPD (Surat Tagihan Pajak Daerah), Surat ini untuk melangsungkan tagihan pajak ataupun sanksi administrasi yang berbentuk bunga ataupun denda sesuai dengan peraturan yang ditetapkan. Sanksi administrasi berupa denda yang dikenakan akibat tidak memenuhi ketentuan yang berlaku. Misalnya terlambat menyampaikan SPTPD. STPD baik diterbitkan pada wajib pajak untuk melakukan kewajiban perpajakan yang dibayarkan sendiri ataupun wajib pajak melaksanakan kewajiban pajak berdasarkan penetapan kepaladaerah.

Kesadaran Wajib Pajak, wajib pajak perlu melaksanakan peraturan dengan baik,benar,dan sukarela. Maka dapat diartikan kesadaran wajib pajak merupakan suatu kondisi wajib pajak mengetahui, menghargai, dan mentaati peraturan perpajakan yang berlaku dan memiliki kesungguhan maupun keinginam untuk memenuhi kewajiban perpajakannya. Adapun petunjuk untuk mengukur tingkat kesadaran wajib pajak adalah :

1. Kesadaran adanya fungsi perpajakan

2. Kesadaran melakukan pembayaran pajak bukan karena tekanan ataupun paksaan dari pihak manapun.

3. Kesadaran adanya manfaat perpajakan yang dibayarkan.

4. Kesadara karena pajak telah diatur oleh Undang-Undang.

Kepatuhan Wajib Pajak, Pembayaran kewajiban perpajakan oleh pembayar pajak dalam rangka memberikan kontribusinya untuk pembangunan negara dan diharapkan dalam pemenuhannya dilakukan dengan sukarela. Kepatuhan menjadi aspek seberapa pentingnya untuk mengingat sistem perpajakan di Indonesia yang menganut system self assessment, dalam proses mutlak memberikan kepercayaan bagi wp untuk menghitung, membayar, dan melaporkan kewajibannya. Adapun petunjuk dalam mengukur kepatuhan wp adalah sebagai beriku :

1. Kepatuhan mendaftarkan diri. 
2. Kepatuhan memberikan kembali surat pemberitahuan.

3. Kepatuhan menghitung dan membayarkan pajak yang terutang .

4. Kepatuhan membayarkan tunggakan.

B. Perilaku Pemilik Restoran yang Segan Mendaftarkan Diri Sebagai Wajib Pajak Restoran

Setiap pengusaha restoran wajib mendaftarkan diri sebagai wajib pajak restoran. Tanggung jawab pajak pemilik restoran dimulai dengan cara menghitung jumlah dari pajaknya sendiri. Selain dari berkewajiban untuk menghitug jumlah pajak dari hasilnya sendiri pemilik restoran mempunyai kewajiban menyetorkan pajaknya ke bank. Selanjutnya ketika sudah menyetorkan pajaknya yaitu melaporkannya kembali.

Perilaku pemilik restoran yang segan untuk mendafatarkan diri sebagai wajib pajak restoran yaitu bagaimana pemilik usaha restoran yang tidak melaksanakan sebagai tanggung jawab terhadap kewajiban pajak yang berada didalam usaha restoran ini. Pemilik restoran berkewajiban dengan perpajakan yang meliputi dari kewajibannya mendaftarkan diri sebagai wajib pajak restoran, menghitung pajak, menyetor pajak, dan melaporankan pajaknya. Dari setiap penghasilan pemiliki restoran maupum itu berupa badan ataupun perseorangan mempunyai tanggung jawab yang wajib dilakukan oleh pemilik restoran tersebut. Berapa jumlah pajak yang harus dibayar ke pemerintah pusat maupun pemerintah daerah. Selain dari kewajiban untuk menghitung sendiri jumlah dari pajaknya pemilik restoran juga mempunyai tanggung jawab untuk menyetorkan pajak ke bank yang sudah ditujukan dari pemerintah. Sesudah menyetorkan pajaknya, wp harus melaporkan pajaknya.

Membahas mengenai perilaku pemilik restoran yang seharusnya mendaftarkan dirinya menjadi wajib pajak dan melaporkan kegiatan usahanya. Tetapi masih kurangnya pengetahuan karena kurangnya sosialisasi ataupun karena kesadaran kewajiban pajaknya yang masih rendah membuat problem dari sisi pajak restoran. Akibat rendahnya kesadaran dan kurangnya sosialisasi membuat kontribusi penerimaan pajak restoran masih belum dapat mengkaji secara optimal.

Selama ini, usaha restoran di Kota Depok jika dilihat dari rekap wajib pajak perjenis pajak sudah terdaftar 1.276 pemilik restoran yang ada di Kota Depok pada tahun 2018 akan tetapi semestinya bisa melebihi 1.276 usaha restoranjika dapat kita lihat di satu kecamatan bisa 2-3 buka usaha baru setiap bulannya. Tetapi masih ada banyak pemilik yang tidak tau dengan pajak restoran ini bisa juga karena lokasi yang terpencil dari pusat kecamatan, maka petugas yang sudah di utus BKD Kota Depok tidak mengetahui adanya usaha restoran tersebut.

Selain itu, data yang menunjukan pada tahun 2018, wajib pajak restoran sebanyak 1.276, akan tetapi ini menjadi data keseluruhan dari wajib pajak restoran 660, rumah makan 303, kafetaria 246, katering 67. Secara garis besar usaha restoran yang ada di Kota Depok telah menjalankan kewajibannya dengan benar. 
C. Tingginya Tingkat Kepatuhan Pemilik Restoran Yang Sudah Terdaftar Wajib Pajak Restoran.

Kewajiban dari pemilik restoran setelah terdaftar jadi wajib pajak yaitu menjalankan kewajibannya dengan baik dan benar. Kewajiban untuk membayarkan pajak tepat waktu, bagi wajib pajak yang telah terdaftar diwajibkan juga untuk membayarkan pajak secara terus menerus. Pajak yang dibayarkan secara rutin tepat waktu dan selalu menjalankan kewajibannya saat telah terdaftar sebagai wajib pajak adalah wujud dari suatu kepatuhan wajib pajak. Tingkat dari kepatuhan wajib pajak restoran yang telah terdaftar kepada kewajiban pajaknya paling utama mengenai pajak daerahnya.

Secara garis besar bahwa tingkat kepatuhan wp restoran yang telah terdaftar sangatlah patuh. Akan tetapi terdapat wp restoran yang telat membayarkan pajak itu sendiri. Berdasarkan data BKD Kota Depok setiap tahun kalau dilihat dari perjenis pajak restoran bagian katering tahun 2016-2018 termasuk masih sangat rendah jika dilihat dari presentasenya yang dari tahun ketahun menurun jika dibandingkan sama jenis pajak restoran, rumah makan, dan kafetaria. Hal ini dapat membuktikan bahwa pemilik restoran, rumah makan, kafetaria, katering patuh akan kewajiban pajaknya akan tetapi dalam pembayaran masih banyak yg kurang bayar. Secara garis besar keseluruhan pemilik restoran telah patuh terhadap kewajiban pajaknya.

Realisasi pajak restoran ini sangat berpengaruh walaupun ada beberapa dari sebagian wp telat membayarkan pajaknya dan kontribusi yang dihasilkan pajak restoran sangatlah mempengaruhi Pendapatan Asli Daerah. Walaupun tingkat dari kepatuhan wp restoran dapat dikatakan sangat memadai, akan tetapi permasalahan lain yang terjadi tentang pajak restoran di Kota Depok adalah menemui wp yang masih belom terdaftar. Adapun permasalahan yang terjadi adalah banyaknya restoran yang masih belum terdaftar diakibatkan kurangnya pengetahuan si pemilik dan kurangnya sosialisasi di masyarakat setempat. Potensi dari penerimaan pajak untuk pemerintah daerah Kota Depok yang besadar sesungguhnya dapat meningkatkan pembangunan, meningkatkan kesejahteraan bagi masyarakat.

D. Realitas Rendahnya Kesadaran Pemilik Restoran Yang Telah Terdaftar Wajib Pajak Restoran

Kesadaran wp restoran terhadap kewajibannya masih bisa dibilang rendah, penyebab salah satunya adalah telat bayar ataupun kurang bayar. Realitas ini terjadi pada pajak restoran di Kota Depok. Kesadaran dari wajib pajak adalah salah satu dari motivasi dalam melakukan kewajiban perpajakannya. Pajak adalah sebagai suatu sumber penerimaan terbesar untuk pembangunan negara, dalam suatu kegiatan pembangunan sangatlah tergantung pada pajak yang diperoleh dari wajib pajak yang membayarkan pajaknya kepada pemerintan dan untuk negara.

Sumbangan yang di hasilkan dari membayar pajak adalah memajukan negara dari pembangunan fasilitas untuk masyarakat. Hal 
tersebut berkaitan pada rendahnya kesadaran dari pemilik restoran untuk mendaftarkan dirinya sebagai wajib pajak restoran.

E. Upaya dan Kendala Badan Keuangan Daerah Kota Depok Dalam Meningkatkan Kepatuhan Wajib Pajak Restoran

Petugas BKD selalu melakukan program sosialisasi dengan pengusaharestoran yang baru buka untuk meningkatkan kepatuhan dalam mendaftarkan usahanya sebagai wajib pajak baru. Tetapi mengenai pendaftaran wajib pajak tersebut tidak dapat dipaksakan dan tergantung pada kesadaran diri dari masing-masing wajib pajak. Hal tersebut yang dapat membuat rendahnya tingkat kesadaran pemilik restoran sebagai wajib pajak restoran.

Dari sisi lain tingkat kesadaran pemilik restoran sebagai wajib pajak restoran, Badan Keuangan Daerah Kota Depok masih mempunyai kendala yaitu kurang pahamnya pemilik restoran dan terlambatnya pelaporan pajak maupun pajak kurang bayar. Kendala yang dialami oleh BKD dalam meningkatkan kepatuhan dari wajib pajak restoran karena mengasut sistem self assesment yang melaporkan, menghitung, dan membayarkan kewajiban perpajakannya secara sendiri. Tapi walaupun terlambat lapor maupun kurang bayar para pemilik restoran mengetahui kewajibannya sebagai wajib pajak restoran.

F. Fakta Kesadaran dan Kewajiban Pemilik Restoran Kepada PajakRestoran

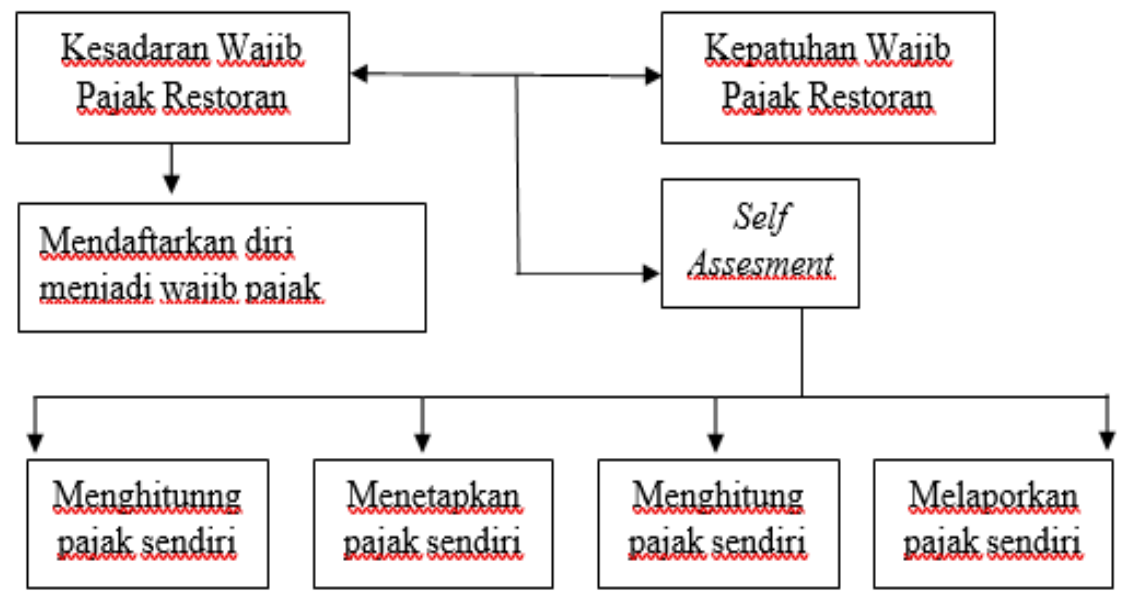

Gambar 2. Kesadaran, Kepatuhan Pajak \& Self Assesment

Kesadaran pemilik restoran saat telah menjadi wajib pajak yaitu melakukan self assesment dengan baik dan benar. Melaporkan pajaknya dengan cekatan tidak kurang bayar dalam membayarkan pajak usahanya itu adalah salah satu prinsip self assesment yang dimiliki pemilik restoran dan menjalankannya dengan baik. Sebagaimana yang dapat kita tahu ternyata pemilik restoran mempunyai rasa tanggung jawab atas pajak restoran nya terhadap pajak daerah.

Undang-Undang nomor 28 tahun 2009 tentang pajak daerah dan retribusi daerah bahwa pajak daerah adalah sumber dari pendapatan 
daerah supaya dapat menjalankan otonomi daerah untuk menjalankan rumah tangganya sendiri, penerimaan yang berasal dari pemerintah berbentuk bantuan subsidi, berbagi hasil dan bukan pajak. Adanya undang-undang tersebut pemerintah dapat menetapkan pajak restoran ini keberbagai jenis pajak restoran, secara lengkap jenis pajak restoran yang berada di kota depok akan ada ditabel berikut.

\begin{tabular}{l|l}
\hline JENIS PAJAK RESTORAN & JUMLAH \\
\hline RESTORAN & 660 \\
\hline RUMAH MAKAN & 303 \\
\hline KAFETARIA & 246 \\
\hline KATERING & 67
\end{tabular}

Tabel 1. Jenis Pajak Restoran Badan Keuanga Daerah Kota Depok 2018

Dari tabel yang ada dijelaskan bahwa pajak restoran mempunyai empat jenis pajak yang ada di dalamnya, terkait dengan pajak tersebut pemilik restoran wajib melakukan kewajibannya sebagai wajib pajak untuk melakukan penghitungan dan pembayaran pajaknya ke bank yang sudah ditunjuk oleh pemerintah. Pemilik restoran mempunyai kewajiban untuk membayarkan pajak kepada pemerintah. Kewajiban tersebut adalah suatu bentuk kesadaran yang dimilki oleh pemilik restoran terhadap pajak.

Penyebab utama dari pemilik restoran tidak melakukan kewajiban pajaknya yang disebabkan oleh besarnya presentase pajak dan terlalu berbelit-belit. Mayoritas dari penyebab tersebut yaitu kurangnya sosialisasi yang terbuka dengan para pemilik restoran yang belum mempunyai kesadaran akan pajaknya. Sehingga dapat disimpulkan pemilik restoran selama ini tidak mendaftarkan usahanya menjadi wajib pajak dikarenakan mereka berfikir usaha restoran ini adalah usaha pribadi jadi tidak perlu mendaftar sebagai wajib pajak, maka itulah penyebab kurangnya kesadaran dari pemilik restoran terkait dengan pajak restoran.

Kesadaran bagi wajib pajak adalah sebuah tindakan baik seseorang dalam memenuhi kewajibannya membayar pajak yang didasari keikhlasan dan ketulusan dari hati nurani. Menurut Nasutian (2016) kesadaran bagi wajib pajak yaitu sikap wajib pajak yang memahami dan ingin melaksanakan kewajibannya membayar pajak dan melaporkan semua pendapatannya tanpa ada yang harus di sembunyikan sesuai dengan peraturan pemerintah (Jurnal, n.d.), dengan begitu dapat dikatakan kesadaran wajib pajak dalam membayarkan pajak adalah perilaku wajib pajak yang merupakan keikhlasannya.

Makna dari kesadaran di atas yaitu bahwa secara alami belum memiliki kesadaran dalam kewajibannya terhadap pajak. Hal tersebut dapat kita lihat masih adanya pemilik restoran yang belum mendaftarakan diri sebagai wajib pajak padahal bisa dibilang tempatnya sangat besar dan pendapatan yg besar pula. Sedangkan Peraturan Pemerintah Daerah Kota Depok Nomor 07 Tahun 2010 mengenai pajak restoran dalam pasal 9 sampai dengan 14 yaitu dengan nama pajak restoran dapat dipungut pajak atas penyediaan makanan atau minuman dan pelayanan oleh restoran, 
objek pajak dari restoran yaitu pelayanan yang di sediakan restoran, subjek pajak dari restoran yaitu badan ataupun orang pribadi yang membeli makanan atau minuman dari restoran.

Berdasarkan peraturan tersebut maka restoran wajib dikenakan pajak sebagai pajak restoran, akan tetapi berdasarkann hasil wawancara dengan informan bahwa selama mendirikan restoran belum melakukan pendaftaran sebagai wajib pajak restoran. Menurut peraturan di atas hal tersebut dapat di simpulkan bahwa pemilik restoran yang seharusnya sudah mendaftarkan dirinya sebagai wajib pajak restoran dengan penghasilan yang sudah selayaknya terkena pajak.

Dasar dari pengenaan pajak restoran menurut Peraturan Pemerintah Kota Depok Nomor 07 Tahun 2010 pasal 12 yaitu dasar dari pengenaan pajak restoran adalah jumlah pembayaran yang seharusnya diterima restoran. Pada pasal 13 yaitu tarif pajak ditetapkan sebesar $10 \%$. Pada pasa 14 yaitu besarnya pokok pajak restoran yang terutang dapat dihitung dengan mengalikan tarif sebagaimana yang dimaksud pada pasal 13 dengan dasar pengenaan pajak yang di maksud dalam pasal 12. Cara perhitungan pajak restoran sebagai berikut:

\section{Pajak Terutang $=$ Tarif Pajak $\times$ Dasar Pengenaan Pajak \\ $=$ Tarif Pajak $\times$ Jumlah Pembayaran yang Seharusnya Diterima Restoran.}

Berdasarkan peraturan daerah mengenai jumlah pembayaran yang seharusnya diterima restoran yaitu jumlah pendapatan yang diterima pemilik restoran dari pelanggan yang membeli makanan atau minuman yang disediakan oleh restoran. Akan tetapi berdasarkan penelitian yang peneliti telah lakukan menunjukan masih ada pemilik restoran yang tidak melakukan kewajiban pajaknya dengan baik.

Kewajiban pemilik restoran seharusnya tidak hanya mendaftarkan diri menjadi wajib pajak, akan tetapi pemilik restoran harus menghitung sendiri jumlah pajak dengan teliti dan benar, selanjutnya membayarkan kepada bank yang sudah ditunjuk oleh pemerintah bisa juga melalui kantor pos, dan melaporkan secara tepat waktu, karena pajak restoran memakai sistem self assesment.

Dalam sistem penghitungan pajak sendiri adalah suatu sistem dengan cara memberikan kepercayaan kepada wajib pajak untuk melakukan sendiri kewajiban dan hak pajaknya. Implementasi sistem tersebut yaitu kegiatan pemungutan pajak ditaruh pada tanggung jawab kepada masyarakat wajib pajak, dimana wajib pajak dikasih kepercayaan untuk menghitung sendiri pajak terutang, memungut pajak sendiri yang harus dipungut, membayarkan sendiri jumlah pajak yang harus dibayar, melaporkan jumlah pajak terutang secara sendiri.

Self asssesment system akan berjalan dengan baik dan benar jika masyarakat wajib pajak memiliki pengetahuan dan kesadaran yang tinggi dalam melakukan kewajibannya sebagai wajib pajak. Jika wajib pajak tidak mempunyai pengetahuan, bagaimana pemilik restoran dapat menghitung sendiri jumlah pajak yang seharusnya dibayarkan. Pemilik restoran juga 
seharusnya mempunyai rasa kepatuhan yang tinggi supaya pajak yang terutang dibayarkan dan dilaporkan tepat waktu.

Permasalahan pajak restoran adalah kurangnya kesadaran dan kepatuhan pemilik restoran untuk mendaftarkan diri menjadi wajib pajak. Pada penelitian (Sucandra \& Supadmi, 2016) menjelaskan bahwa kepatuhan wajib pajak restoran di Kabupaten Badung memiliki peran yang penting untuk meningkatkan pendapatan daerah. Permasalahan tersebut dikarenakan tidak semua subjek pajak memahami dirinya sebagai wajib pajak yang harus melakukan kewajiban pajaknya. Kurangnya kesadaran masyarakat merupakan suatu sinyal terkait dengan kepatuhan terhadap pajak kurang baik. Kepatuhan pajak seharunya dilakukan pada saat syarat terutang pajak dipenuhi. Pada saat pemilik restoran secara sadar memanfaatkan lahannya maka diharapkan pemilik restoran tersebut secara sendirinya dapat memenuhi kewajibannya untuk membayarkan pajaknya, dimulai dengan mendaftarkan dirinya sampai dengan malakukan pembayaran pajak terutang.

Hambatan lain yang terjadi adalah kurangnya efektifitas sistem pemungutan pajak daerah. Sistem yang ada sekarang menuntut wajib pajak agar melakukan kewajibannya membayarkan pajak secara sendiri dengan kata lain Self Assesment System. Akan tetapi kebiasaan masyarakat indonesia yang condong menghindari pajak justru semakin menghambat sistem pemungutan pajak daerah.

Permasalahan dalam pajak restoran yang telah dikatakan oleh peneliti terdahulu secara umum mempunyai kesamaan yang masih banyaknya pemilik restoran yang tidak menjalankan kewajibannya dengan baik. Masih banyak pemilik restoran yang tidak mendaftarkan diri menjadi wajib pajak membuat penerimaan pajak dari sektor pajak restoran yang masih kurang efektif.

Motif dari wajib pajak yang tidak melakukan kewajibannya adalah kurangnya pengetahuan akan pajak restoran, dan tingginya tarif pajak. Motif tersebut dapat terjadi karena besarnya tarif pajak restoran yang membuat para pemilik usaha restoran sebenarnya enggan membayarkannya, dan terkadang pendapatannya tidak sama seperti sebelum sebelumnya pada saat restoran sedan ramai pengunjung.

\section{G. Tingkat Kepatuhan Pemilik Restoran Yang Sudah Terdaftar Sebagai} Wajib Pajak Restoran

Kewajiban pemilik restoran setelah terdaftar sebagai wajib pajak yaitu melakukan kewajiban pajaknya dengan baik dan benar. Kewajiban untuk membayar pajak tepat waktu, bagi wajib pajak yang telah terdaftar diwajibkan untuk membayar pajak secara berkelanjutan. Pembayaran pajak secara tepat waktu dan melakukan kewajiban pajaknya secara rutin saat telah terdaftar menjadai wajib pajak adalah wujud dari kepatuhan wajib pajak.

Kepala Pengelola Sub Bidang Pajak Daerah 1 Badan Keuangan Daerah Kota Depok menjelaskan secara umum bahwa tingkat kepatuhan wajib pajak restoran rata-rata patuh, walaupun masih terdapat wajib pajak yang telat membayarkan pajak dan melaporkannya.Rata-rata pemilik 
restoran yang patuh dengan kewajibannya sebagai wajib pajak restoran, hal ini juga berpengaruh kepada realisasi yang terdapat pada penerimaan pajak restoran. Berikut ini ada tabel target dan realisasi penerimaan pajak restoran di Kota Depok.

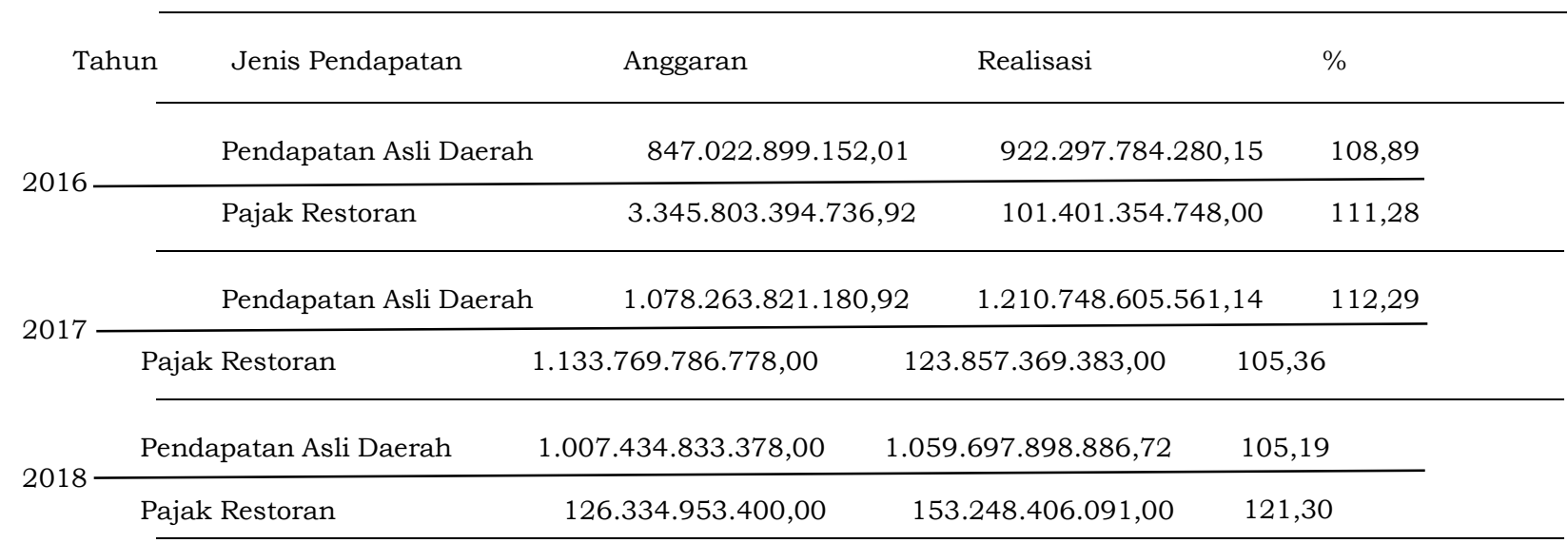

Tabel 2. Target \& Realisasi Penerimaan Pajak Restoran Kota DepokTahun 2016 s/d 2018

Jika dilihat dari tabel yang ada di atas, pada jenis pajak restoran dapat disimpulkan bahwa penerimaan pajak restoran tahun 2016-2018 termasuk masih rendah dilihat dari persentasenya yang pada tahun 2017 menurun, walaupun masih sama diatas 100\% tetapi pada tahun 2017 mengalami penurunan sebesar 5,92\% dari tahun sebelumnya. hal tersebut membuktikan ternyata rata-rata pemilik restoran patuh akan kewajibannya akan tetapi dalam hal pembayaran masih banyak yang kurang bayar ataupun telat tidak tepat waktu. Secara keseluruhan pemilik restoran yang telah patuh terhadap kewajibannya mendaftarkan, membayarkan, dan melaporkannya.

Menurut Kepala Pengelola Sub Bidang Pajak Daerah 1 Badan Keuangan Daerah Kota Depok faktor dari ketidak kepatuhan terutama masalah kurang ataupun telat bayar dikarenakan oleh pemilik restoran yang memang sudah pindah tempat, penjualan menurun, dan restorannya tutup karena bangkrut. Selain dari itu ada faktor lain yang menyebabkan keterlambatan dalam melakukan pembayaran pajak yaitu ternyata adanya slip transaksi yang hilang, maka dari itu Badan Keuangan Daerah Kota Depok mengupayakan adanya pemeriksaan lebih lanjut baik itu pemeriksaan sederhana maupun audit.

Berdasarkan penjelasan yang dijelaskan Kepala Pengelola Sub Bidang Pajak Daerah 1 Badan Keuangaan Daerah Kota Depok mengenai tingkat kepatuhan pemilik restoran dalam kewajiban perpajakan nya yang secara rata-rata wajib pajak restoran di Kota Depok patuh. Kepatuhan bermula dari kata patuh berarti taat pada perintah maupun aturan dan mau disiplin. Kepatuhan dari wajib pajak yaitu sampai mana wajib pajak mampu ataupun gagal dalam berperilaku patuh pada peraturan pajak (Sucandra \& Supadmi, 2016).

Kepatuhan merupakan suatu bentuk perilaku manusia yang berasal dari suatu dorongan berada dalam diri manusia, sedangkan dorongan 
adalah suatu usaha agar memenuhi kebutuhan yang berada dalam diri manusia (Prawagis et al., 2019). Dengan adanya dorongan tersebut didalam diri manusia untuk membayarkan pajaknya maka dapat menaikan jumlah wajib pajak yang membayarkan kewajibannya. Dengan begitu target yang sudah ditetapkan pemerintah dapat tercapai dengan maksimal.

Berdasarkan teori yang berada diatas kepatuhan perpajakan dapat di simpulkan sebagai perilaku yang muncul karena kesadaran dari masyarakat yang telah dinyatakan sebagai wajib pajak, ataupun sudah sesuai dengan persyaratan sebagai wajib pajak yang telah di tetapkan sesuai dengan Undang-Undang yang berlaku dalam memenuhi kewajibannya membayar pajak dengan baik dan benar.

Jika dikaitkan dengan kriteria wajib pajak dapat dikaitkan patuh yaitu sesuai dengan Peraturan Menteri Keuangan Republik Indonesia Nomor 74/PMK.03/2012 tentang tata cara penerapan wajib pajak dengan kriteria tertentu dalam rangka pengendalian pendahuluan kelebihan pembayaran pajak bab II pasal 2 yang disebutkan (Masian, n.d.), wajib pajak dengan kriteria tertentu yang selanjutnya disebut sebagai wajib pajak patuh adalah wajib pajak yang memenuhi persyaratan sebagai berikut:

1. Tepat waktu dalam menyampaikan surat pemberitahuan.

2. Tidak mempunyai tunggakan pajak untuk semua jenis pajak,kecuali tunggakan pajak yang telah memperoleh izin mengangsur atau menunda pembayaran pajak.

3. Laporan keuangan di audit oleh Akuntan Publik atau Lembaga Pengawasan Keuangan Pemerintah dengan pendapat Wajar Tanpa Pengecualian selama 3 (tiga) tahun berturut-turut, dan

4. Tidak pernah di pidana karena melakukan tindak pidana di bidang perpajakan berdasarkan putusan pengadilan yang telah mempunyai kekuatan hukum tetap dalam jangka waktu 5 (lima) tahun terakhir.

H. Rendahnya Tingkat Kesadaran Pemilik Restoran Yang Belum Terdaftar Sebagai Wajib Pajak Restoran

Kesadaran dalam melakukan pembayar pajak tanpa adanya keterpaksaan dan pemeriksaan menggambarkan tentang kepatuhan seorang wajib pajak. Kesadaran dari melaporkan pajaknya secara tepat waktu serta membayarkan pajaknya sesuai dan tepat adalah salah satu dari gambaran kepatuhan wajib pajak.

Tingkat dari kesadaran pemilik restoran di Kota Depok masih sangat kurang. Permasalahannya yaitu mengenai tempat yang jauh dari pusat kota ataupun tempatnya pindah bisa juga tempat sudah tutup, mengganti nomor telepon, pemilik sedang berada di luar kota sehingga petugas BKD sulit menemukan atau menghubungi pemilik restoran. Kalimat tersebut disampaikan oleh Kepala Pengelola Sub Bidang Pajak Daerah 1 Badan Keuangaan Daerah Kota Depok banyak restoran yang ramai akan tetapi rendahnya tingkat kesadaran pajak restoran tidak dapat digali dengan optimal.

Berdasarkan wawancara dengan Kepala Pengelola Sub Bidang Pajak Daerah 1 Badan Keuangaan Daerah Kota Depok jika pemerintah yang lebih tinggi seperti halnya Direktorat Jendral Pajak maupun Kantor Pelayanan 
Pajak Pratama menemukan wajib pajak yang bandel yaitu seperti pemilik itu sudah susah akan dibawa kepengadilan pajak, akan tetapi Pemerintah Daerah level Provinsi Kabupaten Kota belum pernah bertarung sampai kepengadilan pajak, sampai tingkat penyitaan pun tingkat dinas belum mempunyai juru sita karena kurangnya sumber daya manusia.

Keterbatasan petugas dari Badan Keuangan Daerah Kota Depok untuk tahap penyitaan kurang maksimal karena keterbatasan sumber daya manusia oleh karen itu Badan Keuangan Daerah Kota Depok bekerja sama dengan KPP Pratama untuk meminjam petugasnya seperti yang di sampaikan oleh Kepala Pengelola Sub Bidang Pajak Daerah 1 Badan Keuangaan Daerah Kota Depok.

Pemilik restoran yang belum terdaftar sebagai wajib pajak restoran karena ketidak tahuannya petugas pajak harus melakukan sosialisasi baik diwiliyah terpencil sehingga pemilik restoran yang belum terdaftar menjadi tahu akan kewajibannya terhadap pajak restoran karena mereka hanya membayar pajak bangunan saja.

Pemilik restoran masih banyak yang belum memenuhi kewajiban pajaknya yang belum terdaftar sebagai wajib pajak ataupun pemilik yang sudah terdaftar sebagai wajib pajak restoran tidak membayarkan pajak yang seharusnya dibayarkan. Definisi kepatuhan pajak dalam peraturan menteri keuangan juga dijelaskan menyangkut dengan kriteria wajib pajak yang patuh.

Kesadaran akan kewajiban pajak salah satu penyebab wajib pajak menjadi patuh ataupun tidak patuh. Pada saat wajib pajak mempunyai kesadaran yang tinggi menyangkut kewajibannya maka wajib pajak tersebut selanjutkan menjalankan kewajibannya, tetapi jika wajib pajak tidak mempunyai kesadaran terkait pentingnya pajak maka wajib pajak pasti mengabaikan kewajibannya.

I. Sosialisasi Salah Satu Upaya Dalam Meningkatkan Kesadaran Pemilik Restoran Dalam Kepatuhan Sebagai Wajib Pajak Restoran

Meningkatkan kepatuhan wajib pajak baik yang sudah terdaftar ataupun dalam upaya pencarian wajib pajak yang harus dilakukan secara berlanjutan karena wajib pajak perlu bimbingan juga pertumbuhan wajib pajak dari tahun ke tahun yang mengalami peningkatan membutuhkan suatu upaya yang serius dalam meningkatkan kontribusi pajak yang paling utama adalah pajak restoran. Sosialisasi suatu cara untuk meningkatkan kepatuhan bagi wajib pajak maupun yang belum terdafar sebagai wajib pajak restoran.

Menurut Saragih, 2013 sosialisasi pajak yaitu upaya dari Dirjen Pajak untuk memberi informasi, pengertian, dan pembinaan pada masyarakat umumnya dan wajib pajak khususnya mengenai suatu yang berhubungan dengan pajak dan perundang- undangan perpajakan (Savira \& Suharsono, 2013).

Bentuk dari sosialisasi perpajakan menurut Susanto, 2012 sosialisasi dapat dikelompokkan melalui metode penyampaian, segmentasi ataupun medianya : 
1. Berdasarkan Metode

Penyampaian melalui acara yang formal maupun informal. Acara formal menggunakan format acara yang disusun secara resmi. Acara informal menggunakan format acara yang tidak resmi atau santai.

2. Berdasarkan segmentasi

Membagi kepada suatu kelompok umur tertentu, kelompok pelajaran dan mahasiswa, kelompok pengusaha tertentu, kelompok profesi tertentu, dan kelompok ormas tertentu.

3. Berdasarkan media yang digunakan

Sosialisasi dapat dilakukan dengan media elektronik maupun media cetak, seperti halnya talkshow di televisi atau radio, membuat opini terkait, tanya jawab dikoran melalui ulasan, majalah ataupun tabloid. Bentuk dari propaganda lainnya seperti spanduk, banner, papan iklan dll.

(Herlambang et al., 2018) bahwa Ditjen Pajak mempunyai beberapa point menyangkut indicator dalam sosialisasi dimana kegiatan tersebut mampu memberikan kesadaran dan mempunyai rasa peduli dengan pajak yang diperbaharui dari suatu perkembangan pelayanan program pajak.

1. Penyuluhan, Ditjen Pajak membentuk suatu sosialisasi dengan menggunakan media masa maupun media elektronik yang menyangkut dengan peraturan perpajakan bagi wajib pajak.

2. Berdiskusi Secara Langsung dengan Tokoh Masyarakat dan Wajib Pajak Komunikasi yang diberikan oleh Ditjen Pajak mempunyai komunikasi dua arah yaitu wajib pajak dengan petugas pajak ataupun dengan masyarakat yang dapat berpengaruh pada pandangan masyarakat sekitarnya.

3. Informasi Langsung dari Petugas ke Wajib Pajak, Petugas memberikan informasi langsung kepada wajib pajak terkait dengan peraturan perpajakannya.

4. Pemasangan Papan Iklan maupun Spanduk, Pemasangan spanduk pada tempat yang strategis memudahkan untuk dilihat masyarakat. Isi yang terkandung didalamnya merupakan pesan singkat berupa perkataan, pernyataan dengan bahasa yang mudah untuk dipahammi oleh masyarakat.

5. Website Ditjen Pajak, Bentuk dari website yang dapat diakses internet setiap saat, cepat, mudah, dan mempunyai banyak informasi yang lengkap.

Badan Keuangan Kota Depok memberikan gambaran terkait dengan sosialisasi pajak yang berlangsung dalam lapangan supaya para pengusaha restoran yang baru buka mempunyai rasa sadar dan patuh akan kewajibannya dengan pajak dari usaha yang dibuatnya. Kesadaran mereka membuat sosialisasi pajak secara langsung kurang sepenuhnya terealisasi hingga saat ini, dikarenakan masih banyaknya para pengusaha restoran tidak menghadiri sosialisasi yang telah diselenggarakan oleh Badan Keuangan Daerah Kota Depok, keterlibatan aparatur lain juga dibutuhkan. Melalui pembicaraan pihak kejaksaan dan kepolisian dapat menjadi sambungan antara Badan Keuangan Daerah Kota Depok dengan 
masyarakat. Akan tetapi kurangnya kesadaran dari pengusaha restoran untuk menghadiri sosialisasi tersebut.

Menurut (Herlambang et al., 2018) sosialisasi yang dilakukan petugas pajak untuk sosialisasi secara langsung dan melalui media dengan memanfaatkan brosur dan spanduk dalam melakukan sosialisasi. Dalam Surat Edaran Direktur Jendral Pajak Nomor SE-22/PJ.2007 terkait Penyeragaman Sosialisasi Perpajakan Bagi Masyarakat ada beberapa contoh media informasi antara lain :

1. Media Informasi, Informasi tentang pajak bersumber banyak dari media masa, tapi media luar ruang juga sumber informasi pajak yang diperhatikan masyarakat. Berdasarkan hal ini maka media informasi lebih banyak digunakan dalam sosialisasi perpajakan. Contoh dari beberapa media informasi yang dimaksud antara lain seperti, Media Koran, Media Radio, Media Televisi, Media Spanduk, Media Brosur.

2. Slogan, Ada beberapa hal yang harus diperhatikan dalam pembuatan slogan yang menjadi alat untuk sosialisasi perpajakan kepada masyarakat secara luas. Slogan tidak boleh bersifat intimidasi, tetapi bersifat ajakan. Slogan harus ditekankan pada kata manfaat pajak yang dihasilkan seperti, contoh dari slogan peringkat tertinggi karena kriteria manfaat (Lunasi Pajaknya Awasi Penggunaannya).

3. Cara Penyampaian informasi sebaiknya menggunakan bahasa yang sesederhana mungkin dan tidak bersifat teknis, sehingga informasi dapat diterima dengan baik.

4. Kualitas Sumber Informasi, Informasi terkait dengan pajak dirasa masih kurang oleh masyarakat. Sumber informasi dinilai informatif dan dibutuhkan sebagai berikut, Penyuluhan, Call Center, Televisi, Internet, Petugas Pajak, Iklan Bus.

5. Materi Sosialisasi, yang disampaikan harus ditekankan dengan manfaat pajak, NPWP danpelayanan pajak di setiap bagian.

6. Kegiatan Penyuluhan, yang perlu diperhatikan dalam kegiatan penyuluhan ini adalah Metode diskusi, Media melalui proyektor, Materi pengisian SPT dan pengetahuan lainnya yang membantu, Pembicara harus menguasai materi

Dalam melakukan sosialisasi memerlukan strategi yang matang supaya kegiatan sosialisasi dapat berjalan dengan baik dan benar, serta mendukung kinerja yang efisien dalam setiap kegiatan sosialisasi yang dilakukan. Menurut Winerungan, 2013 dijelaskan mengenai strategi yang dimaksud adalah sebagai berikut:

1. Publikasi, aktivitas publikasi melalui media komunikasi dan media cetak seperti surat kabar, majalah, maupun media audio visual seperti halnya radio dan televisi.

2. Kegiatan, institusi dari pajak melibatkan diri pada penyelenggaraan aktivitas tertentu yang berhubungan dengan program peningkatan kesadaran dan kepatuhan masyarakat akan pajak pada momen tertentu. Misalnya kegiatan hari libur nasioanal, kegiatan olahraga, dan lain sebagainya.

3. Pemberitaan, menjadi bahan untuk sebuah berita dalam artian yang positif, sehingga menjadi saran untuk promosi yan efektif. Pajak 
dapat disosialisasi berbentuk berita untuk dikonsumsi oleh masyarakat, sehingga masyarakat dapat lebih mudah untuk menerima informasi terkait pajak.

4. Keterlibatan komunitas, suatu komunitas adalah cara untuk mendekatkan institusi pajakkepada masyarakat, karena iklim budaya indonesia masih memakai adat ketimuran untuk bersilaturahmi kepada tokoh setempat sebelum intitusi pajak dibuka untuk umum.

5. Pencantuman identitas maupun logo otoritas pajak pada media ditunjukan untuk sarana promosi.

6. Lobbying, secara pribadi dilakukan dengan formal untuk mencapai tujuan tertentu. Strategi pendekatan tersebut dilakukan pada tempat terpencil maupun keadaan lainnya yang diperlukan. Sosialisasi harus dilakukan secara langsung atau dari rumah ke rumah masyarakat maupun wajib pajakyang butuh disosialisasi.

Strategi diperlukan dalam melakukan sosialisasi yang bertujuan untuk meningkatkan kepatuhan wajib pajak yang masih belum terdaftar. Tujuan dari sosialisasi yaitu untuk meningkatkan kepatuhan wajib pajak yang sudah terdaftar dan meningkatkan pencarian bagi wajib pajak yang masih belum terdaftar. Sejauh ini upaya dalam melakukan sosialisasi oleh Badan Keuangan Daerah Kota Depok dapat meningkatkan kepatuhan bagi wajib pajak yang sudah terdaftar, akan tetapi sosialisasi yang dilakukan masih kurang dalam melakukan pencarian wajib pajak yang belum terdaftar secara optimal.

Saat melakukan pencarian wajib pajak yang belum terdaftar memang diperlukan sosialisasi secara langsung atau mendatangi langsung secara tatap muka itu adalah cara yang potensial. Dalam pendaftaran wajib pajak yang baru sangat minim sekali wajib pajak yang bersedia mendaftarkan diri menjadi wajib pajak. Keterbatasan dalam petugas pajak lapangan menjadi permasalahan sendiri. Secara teori di jelaskan oleh Herryanto dan Tolly, 2013 kegiatan sosialisasi pajak dapat dibagi menjadi 3 fokus, yaitu :

1. Sosialisasi untuk calon wajib pajak, bertujuan agar membangun kesadaran pentingnya pajak, dalam penelitian ini pada pajak daerah sering menemukan wajib pajak baru, sosialisasi bagi wajib pajak baru mempunyai tujuan meningkatkan pemahaman, kepatuhan untuk memenuhikewajiban pajak.

2. Sosialisasi untuk wajib pajak baru, mempunyai tujuan meningkatkan pemahaman dan kepatuhan agar memenuhi kewajiban pajak khususnya untuk mereka yang tidak pernah menyampai SPT, penelitian ini dikhususkan pada e-SPTPD, dan melakukan penyetoran pajak.

3. Sosialisasi untuk wajib pajak yang sudah terdaftar, mepunyai tujuan menjaga komitmen wajib pajak untuk patuh.

Tujuan dari sosialisasi diatas dibagi menjadi tiga fokus. Sosialisasi untuk calon wajib pajak terutama wajib pajak pemilik restoran bertujuan agar meningkatkan pemahaman, kesadaran betapa pentingnya pajak. Sedangkan untuk wajib pajak baru menpunyai tujuan agar wajib pajak terutama pemilik restoran paham menyangkut bagaimana menyampaikan 
e-SPTPD dan cara menyetorkan pajak. Sosialisasi selalu dilakukan supaya wajib pajak yang telah terdaftar terutama pemilik restoran tetap menjaga komitmen dalam kepatuhan pajaknya. Sehingga dapat diambil makna bahwa sosialisasi wajib dilakukan secara berulang.

Sosialisasi pajak sangat dibutuhkan untuk perpajakan agar berjalan dengan baik dan benar. Permasalahan menyangkut banyaknya wajib pajak yang belum terdaftar, dalam hal tersebut Badan Keuangan Daerah Kota Depok harus melakukan sosialisasi. Hal tersebut mempunyai tujuan membangun kesadaran tentang pentingnya pajak, dalam penelitian tersebut pajak daerah yang utama pajak restoran, mencari wajib pajak baru, sosialisasi wajib pajak baru mempunyai tujuan meningkatkan pemahaman dan kepatuhan memenuhi kewajiban pajaknya.

Sosialisasi dilakukan oleh Badan Keuangan Daerah Kota Depok masih dapat mencari pemilik restoran yang secara aturannya sudah memenuhi syarat untuk menjadi wajib pajak restoran. Tetapi pada saat mau melakukan penelitian masih banyak yang ditemukan pemilik restoran tidak membayarkan pajak restoran sesuai dengan omset pendapatannya, dikarenakan kurangnya dari kesadaran untuk menghadiri sosialisasi dari Badan Keuangan Daerah Kota Depok.

\section{PENUTUP}

Pembahasan tersebut telah dilakukan analasis yang sesuai dengan pendekatan etnometodologi dalam paradigma interpretif. Berdasarkan dari pembahasan yang sudah dilakukan, dapat ditarik dengan kesimpulan bahwa masih banyak ditemukan pemilik restoran yang tidak bertanggung jawab terhadap kewajiban pajak usahanya. Secara garis besara permasalahan pajak restoran di Kota Depok yaitu masih banyak pemilik restoran yang masih belum melakukan kewajiban sebagai wajib pajak. Tidak menghadiri sosialisasi tentang pajak restoran yang kelak akan menjadi permasalahan atas mengapa pemilik restoran tidak menjadi wajib pajak restoran.

Penelitian ini dapat diharapkan menjadi dasar bagi penelitian berikutnya serta dapat mengetahui Kesadaran Wajib Pajak Restoran Dalam Kepatuhan Pelaporan Pajak Menggunakan Aplikasi E-SPTPD di Kota Depok. Bagi penelitian berikutnya diharapkan dapat menjadi bukti empiris pada literatur untuk bahan dasar pengembangan ilmu dibidang akuntansi perpajakan khususnya di bidang perpajakan daerah yaitu pajak restoran.

Kendala yang dihadapi Badan Keuangan Daerah dalam menghadapi wajib pajak restoran adalah rendahnya kesadaran dari si pemilik restoran dan lokasi nya sulit untuk di deteksi oleh petugas lapangan. Kendala lainnya adalah karena pemilik restoran sudah tau akan kewajibannya tetapi lalai dalam mendaftarkan diri sebagai wajib pajak dan yang sudah terdaftar sebagai wajib pajak restoran kasusnya ada yang telat bayar, ada yang kurang bayar dan sengaja tidak membayarkan pajak restoran. Secara garis besar permasalahan pajak restoran di Kota Depok yaitu masih ada pemilik restoran yang belum melakukan kewajiban sebagai wajib pajak. Tidak menghadiri sosialisasi tentang pajak restoran yang kelak menjadi 
permasalahan atas ketidak tahuan atau kurangnya ilmu perpajakan sebagai wajib pajak restoran. 


\section{DAFTAR PUSTAKA}

Anugrahi, R., Manossoh, H., \& Tangkuman, S. J. (2018). Analisis Kontribusi Pajak Restoran Terhadap Pendapatan Pajak Daerah Pada Badan Pengelola Pajak Dan Retribusi Daerah Kabupaten Minahasa Selatan. Going Concern : Jurnal Riset Akuntansi, 13(4), 191-199. https://doi.org/10.32400/gc.13.04.20981.2018

Aznedra. (2017). PENGARUH KONTRIBUSI PENERIMAAN PAJAK HOTEL DAN PAJAK RESTORAN TERHADAP PENDAPATAN ASLI DAERAH DI WILAYAH KOTA BATAM TAHUN 2012-2014 (Studi Kasus Dinas Pendapatan Asli Daerah di Kota Batam). Jurnal Dimensi, 6(2), 235-255. https: / / doi.org/ 10.33373/dms.v6i2.1049

Basyarahil, E. L., \& Irmadaryani, R. (2019). Efektivitas dan Kontribusi Pajak Hotel dan Pajak Restoran Terhadap Penerimaan Pendapatan Asli Daerah (PAD) Kabupaten Jember. E-Journal Ekonomi Bisnis Dan Akuntansi, 6(2), 135-140. https://doi.org/10.19184/ejeba.v6i2.11157

Fitrianda, M. I. (2013). PROSEDUR PELAPORAN PAJAK RESTORAN MELALUI SISTEM E-SPTPD PADA BADAN PENDAPATAN DAERAH KABUPATEN JEMBER.

Goleman, D., Boyatzis, R., \& Mckee, A. (2019). PERATURAN DAERAH KOTA DEPOK NOMOR 07 TAHUN 2010 TENTANG PAJAK DAERAH. Journal of Chemical Information and Modeling, 53(9), 1689-1699.

Herlambang, A. A., Hernawati, E., \& Widiastuti, N. P. E. (2018). Dampak Sosialisasi Perpajakan Bagi Pemilik Usaha Pada Sektor Usaha Mikro Dan Kecil: Faktor Pemahaman Dan Kepatuhan Pajak. ULTIMA Accounting, 10(1), 77-95.

https://doi.org/10.31937/akuntansi.v10i1.834 Jurnal, U. (n.d.). $B A B$ II. 9-28.

Kogler, C., Batrancea, L., Nichita, A., Pantya, J., Belianin, A., \& Kirchler, E. (2013). Trust and power as determinants of tax compliance: Testing the assumptions of the slippery slope framework in Austria , Hungary, Romania and Russia. Journal of Economic Psychology, 34, 169-180. https://doi.org/10.1016/j.joep.2012.09.010

kompas.com. (n.d.). 40 Restoran di Depok Menunggak Pajak, Alasannya Lupa. 2018. Retrieved November 28, 2020, from https://megapolitan.kompas.com/read/2018/11/09/16561851/40restoran-di-depok-menunggak-pajak-alasannya-lupa\#

Masian. (n.d.). KAJIAN PUSTAKA, KERANGKA PEMIKIRAN DAN HIPOTESIS. 17-65.

Mediawati, N. N. . (2018). Jurnal Ekonomi dan Bisnis Airlangga KESADARAN PERSEPSI TENTANG WAJIB PAJAK RESTORAN DI KOTA PALU. 28(2), 117-127. https://doi.org/10.20473/jeba.V28I22018.5823

Mintahari, M. W., \& Lambey, L. (2016). Analisis Kontribusi Pajak Restoran Terhadap Pendapatan Asli Daerah (Pad) Kabupaten Minahasa Selatan Tahun 2012-2014. Jurnal Riset Ekonomi, Manajemen, Bisnis Dan Akuntansi, 4(2), 641-651.

Muslim. (2016). VARIAN-VARIAN PARADIGMA, PENDEKATAN, METODE, DAN JENIS PENELITIAN DALAM ILMU KOMUNIKASI. Wahana, 1(10), 
77-85.

Prawagis, F. D., Z.A, Z., \& Mayowan, Y. (2019). PENGARUH PEMAHAMAN ATAS MEKANISME PEMBAYARAN PAJAK, PERSEPSI TARIF PAJAK DAN SANKSI PAJAK TERHADAP KEPATUHAN WAJIB PAJAK UMKM (Studi Pada Wajib Pajak Yang Terdaftar di KPP Pratama Batu). Journal of Chemical Information and Modeling, 53(9), 1689-1699.

Rindri, A. G. (2011). Metode_Penelitian_Kualitatif_dan_Kuantit.

Ruung, N. V., Ilat, V., \& Wokas, H. R. . (2017). ANALISIS KONTRIBUSI DAN PELAPORAN PAJAK HOTEL DAN PAJAK AIR TANAH TERHADAP PENDAPATAN ASLI DAERAH KOTA MANADO. Jurnal Riset Akuntansi Going Concern, 12(2), 1196-1204.

Savira, F., \& Suharsono, Y. (2013). Sosialisasi Pajak. Journal of Chemical Information and Modeling, 01(01), 1689-1699.

Sayekti, F., \& Putarta, P. (2016). Penerapan Technology Acceptance Model (TAM) Dalam Pengujian Model Penerimaan Sistem Informasi Keuangan Daerah. Jurnal Manajemen Teori Dan Terapan, 9(3), 196-209.

Setiawan, A. R., Al-Fauzi, M. L., \& Prathama, A. (2020). IMPLEMENTASI ESPTPD (SURAT PEMBERITAHUAN PAJAK DAERAH BERBASIS ELEKTRONIK) DALAM PENGELOLAAN KEUANGAN DAN PAJAK DAERAH DIKOTA SURABAYA / Jurnal Syntax Transformastion, Vol 1, No 2 April 2020. 1(2), 1-10.

Sucandra, L. K. I. P., \& Supadmi, N. L. (2016). Pengaruh Kualitas Pelayanan, Pemeriksaan Pajak, Pengetahuan Perpajakan Dan Sanksi Perpajakan Pada Kepatuhan Wajib Pajak Restoran. E-Jurnal Akuntansi, 16(2), 1210-1237.

Suleman, D. (2017). Kontribusi Pajak Restoran Terhadap Pendapatan Asli Daerah Dispenda Kabupaten Bogor. Jurnal Moneter, IV(2), 139-144.

Sulistiyowati, \& Sabila, N. (2018). Analisis Pelaksanaan Online System Pajak Daerah Dalam Rangka Penerimaan Pajak Hiburan dan Pajak Restoran pada Suku Badan Pajak dan Retribusi Daerah Kota Administrasi Jakart Pusat Tahun 2014- 2016. Jurnal STEI Ekonomi, 27(1), 121-137. https://doi.org/10.36406/jemi.v27i1.157

Suradiansyah, A., Widiastuti, N. P. ., \& Aziz, A. (2019). Makna yang timbul dari kesadaran membayar pajak restoran. Jurnal Riset Bisnis, 3(1), 5465.

http://journal.univpancasila.ac.id/index.php/jrb/article/view/980/639

Susanti Yenny. (n.d.). Etnometodologi dalam Penelitian Kualitatif - The umbrella of my fantasy. The Umbrella of My Fantsy. Retrieved October 26, 2020, from https://yenipsa08.blog.uns.ac.id/2010/11/26/etnometodologi-dalampenelitian-kualitatif/

Walasik, A. (2015). The Propensity to Tax Competition: The Case of Implementation Local Tax Policy by Polish Local Governments. Eurasian Journal of Economics and Finance, 3(1), 28-37. https:/ / doi.org/10.15604/ ejef.2015.03.01.004

Yunus, R. M., \& Cartinah, T. (2000). RANCANG BANGUN SURAT PEMBERITAHUAN PAJAK DAERAH ( E-SPTPD ) BERBASIS WEB PADA BADAN KEUANGAN DAN ASET DAERAH. POLBAN, 295-302. 